\title{
The Arabic Language Level of Candidates for Malaysia Religion High Certificate (MRHC): Reading and Grammar
}

\author{
Ismail Muhamad ${ }^{1}$, Hazwan Abdul Rahman ${ }^{2} \& \mathrm{Azman}_{\mathrm{Che}} \mathrm{Mat}^{3}$ \\ ${ }^{1}$ Faculty of Social Development, Universiti Malaysia Terengganu, Terengganu, Malaysia \\ ${ }^{2}$ Institut al-Quran Terengganu, Kampus Padang Midin, Terengganu, Malaysia \\ ${ }^{3}$ Academy of Language Studies, Universiti Teknologi MARA (UiTM) Dungun, Terengganu, Malaysia \\ Correspondence: Azman Che Mat, Academy of Language Studies, Universiti Teknologi MARA (UiTM), \\ Dungun Campus, 23000 Dungun, Terengganu, Malaysia. E-mail: azman531@tganu.uitm.edu.my
}

Received: July 23, 2014 Accepted: August 26, 2014 Online Published: October 30, 2014

doi:10.5539/ass.v10n22p156 URL: http://dx.doi.org/10.5539/ass.v10n22p156

\begin{abstract}
Malaysia Religion High Certificate (STAM) examination is a Malaysian student's eligibility to study in the Middle East. STAM was introduced in 2000 as a result of a Memorandum of Understanding Cultural Agreement between the Governments of Malaysia and the Arab Republic of Egypt in November 1999. But many STAM graduates who took the language test at the university had failed to get the level of qualification and had to take Arabic classes at the language center before pursuing studies at the undergraduate level. This study aims to identify the level of text reading in Arabic among STAM candidates and Arabic grammar skills. Therefore, the researchers aim of 52 students who is a STAM candidate to participate in this study. The approach used in this study is quantitative; wherein the information gathered is presented in the Figures. Data collection using a measurement tool based on the study of texts authored by Sheikh Yusuf al-Qaradawi containing 448 words. Comprehension and grammar skills tests were done for collecting data and then presented into numbers. The findings showed that the respondents' reading and grammar level are moderate. Therefore, it is recommended that students who will take the STAM are given proper guidance so that they can improve their Arabic language proficiency before pursuing studies at tertiary institutions.
\end{abstract}

Key words: proficiency, reading, syntax, candidate, STAM

\section{Introduction}

Generally, language skills are categorized into two types of communication, the received and conveyed communications. Received communications are associated with listening and reading skills. Whereas conveyed communication is related to speaking and writing (Talib, 1993, p. 35). Reading is a language skill activity that aims at understanding any written materials. It is not considered as a language skill activity if the purpose of reading is not to give a solid comprehension (Dawud, 1990, p. 15). Thus, reading skill is one's ability to effectively understand the messages or information that the author presented in writing. Al Ramini (2009, p. 53) further explains that reading is one of the essential skills in the process of teaching and learning, coming in second after listening skill as a mean to gather information, details as well as recognizing people's feelings.

Language proficiency is identified through familiarity and discern of vocabulary particularly in forms and sounds of letters, as well as meanings. Students are also required to master grammatical rules and assimilate them with all four aspects of language skills which cover listening, speaking, reading and writing (Husin, 1988, p. 274; Tu'aimah, 1985, p. 167; Aziz, 1983, p. 138; Lado, 1980, p. 11).

However, the Arabic language is peculiar with variants that are not seen in any other languages of the world and these differences may be seen as unique features that reflect the language of the Quran. The language system of Arabic uses case endings in which certain lines [signs] are attached to the word's grammatical functions. They are $\operatorname{marf} \bar{u}^{c}$ (nominative), manșūb (accusative), end (jusitive) and majrūr (genitive), which also represent word placements in sentences or better known as flexible case (Rahman \& Mezah, 2010, p. 82). Therefore, one needs to read Arabic guided by these grammatical cases [signs] on each word to fully understand the meaning of a sentence. 
Mastery of the Arabic language is determined by students' capabilities in empowering the language through listening, speaking, reading and writing accompanied with the ability to apply all aspects of the language, which includes grammar ( $\mathrm{nahu}$ ), root words (saraf), vocabulary, and of course the Arabic writing system (Rusoff, 2008, p. 183; Ahmad et al., 2011, p. 385).

Malaysian Religion High Certificate (STAM) was introduced in the year 2000 as a result of an agreement between the Malaysian government and Arab Republic of Egypt in the Memorandum of Cultural Understanding in November 1999 (Rejab, 2001, p. 176). Number of enrollment has increased from 160 students in the year 2001 and up until the year 2007 a total of 670 students had registered. In 2011, 571 students managed to participate in a bachelor's program in Egypt. However, they were required to sit for the qualifying examination (Imtihān Al-Qabul) in advance. According to the performance report issued by the Malaysian Examination Board, only two students are eligible to attend lectures at the university whilst the remainder of 569 students had to take the Arabic language course in the Arabic Language Centre. The same report also stated that a number of 6584 students had failed in the exam. Such large number of failure surprised many people, especially examination boards, sponsors and parents of students (STAM Yearly Report, 2012). As such, this study intends to examine the level of Arabic language proficiency of STAM candidates based on these two objectives:

1) Identifying the level of reading comprehension in the Arabic language among students of Malaysian Religion High Certificate (STAM) at the Institute of Al-Quran in Terengganu.

2) Recognizing the level of Arabic syntax among students of Malaysian Religion High Certificate (STAM) at the Institute of the Al-Quran in Terengganu.

\section{Literature Review}

Reading is not limited only to the mere process of transferring writing into language but it is also a skill of grasping and interpreting the meaning of written materials as well as verbal symbols (Harris \& Sipay, 1981, p. 447; Husin, 1988, p. 157). Reading without comprehension of the written material is not considered as the actual act of reading (Dawud, 1990, p. 15). Abdul Aziz (1989, p. 254) and Lado (1980, p. 177) explained that reading is an act that yields understanding as well as recognition of words and pronunciation. The most important part of reading is the actual comprehension itself even when reader is unable to pronounce each word fluently.

Comprehension means the ability to establish, interpret as well as evaluate anything that relates to what is being read. It is also a process of retrieving meaning via communicative tools, either verbal, written or of specific symbols, at the same time encompassing complex mental processes such as identification, selection of meaning, forming generalization and providing assessment (Rohani, 1987, p. 167). According to Harris and Sipay (1981, p 8), comprehensive reading is a result of interaction between perception towards graphical symbols that represents an individual's skills in reading and knowledge in grammar. Thus, the act of reading and the ability to comprehend what is being read is a relationship that complements each other. Without comprehension, a reading action is incomplete and is not valid (Yusoff, 1999, p. 85; Zalizan, 1987, p. 115).

There are several sets of skills that need to be mastered in the aspect of reading Arabic. They are:

1) Reading speed: the length of time taken by a normal student to form words being read to the next word.

2) Intonation: student's ability to style voice tones in accordance with the changes in a sentence and idiolect used.

3) Reading has to be parallel with the language's discourse.

4) Placements of case endings on each word according to Arabic syntax.

5) Proper utterance of each word.

6) Recognizing the peculiarity in different letters with similar sounds.

7) Pronunciation of phonemes is precisely on makhraj.

8) Correct pronunciation of each letters with the character it represents.

9) Avoiding speech errors: inaccuracy that stems from defects in speech tools and slow growth rates.

Arabic syntatactic aspects play an important role in reading Arabic. This is because in Malay or English, words are uttered and pronounced based on spelling and syllable (Suhaila et al., 2001). Whereas Arabic words need specific grammatical cases [signs] on each letter to form a word with meanings. Which is why it is crucial to have proper knowledge on every aspect of Arabic syntax so they can be applied into text comprehension. This study focuses on some essential Arabic syntax such as: 


\section{1) Mubtada' (مبندأ) Subject}

Mubtada' refers to Nouns in Arabic (Jinnī, 1988, p. 29) or Derivatives (Hishām, 1997, p. 106). In which the subject is placed with a suffix ( $i^{\prime} \mathrm{rab}$ ) of a nominative case ending ( $\left.\mathrm{raf} \mathrm{f}^{\prime}\right)$ in accordance with its position, which is at the beginning of a sentence. For example:

الطالبُ ذكي: "The student (he) is smart"

The example above shows that the word (الطالب) is a mubtada'. It is also known as a noun that is placed at the beginning of a sentence (al-Khammāsh, 2007, p. 109). The nominative case ending seen on the last letter $b a$ ', denotes the placement of $i$ 'rab.

2) Khabar (خبر)Predicate

Khabar is an important element in the completion of a sentence along with Mubtada'. Three types of Khabar, they are khabar mufad, khabar jumlah and shibih jumlah. (Jinnī, 1988, p. 29; al-Maghālasah, 2007, p. 228; 'Aqil, 1990, p. 175; Mustafā, 2007, p. 252). Khabar mufrad consists of the noun jāmid and verb mushtaq. (Hishām, 1997, p. 109). Placement of $i$ 'rab is similar to mubtada'. For example:

\section{خالد مجتهـ" "Khalid is a hardworking boy"}

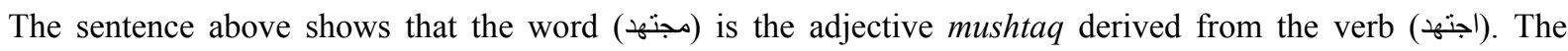
nominative case ending on the letter $d \bar{a} l$ makes it a khabar.

"زوجته قمر: "His wife (is like) the moon"

Whereas in this second example, the word (قمر) is the noun jämid, which is a noun that does not derive from a verb. (Babitī 1992: 402). Again, the nominative case ending on the letter $r a$ makes it a khabar.

\section{3) Fa'il (فاعل) Doer}

Nominative noun that comes after a verb in an active sentence. It refers to a person committing an act or an act deemed on someone (al-Shajrāwi, 2001, p. 165; Ali \& Mustafa, 2007, p. 37). Fa'il comes in several conditions, such as ism Sarīh, bāriz or hidden pronouns and invented derivatives (al-Shajrāwi, 2001, p. 166; al_Bayjūri 2011, p. 100). For example:

قام زيد: "Zaid has stood (up)"

The above example puts Zaid as a fa'il (doer) in the form of Ism Sarīh with nominative case ending as an i'rab.

4) Maf'ūl bih (مفعول به) Object (that follows after the verb)

Nouns denoting something or someone that the verb is being done to. Marked by the accusative case ending as its i'rab (al-Qirshī, 2004, p. 94; Ali \& Mustafa, 2007, p. 40). It is found in two conditions, firstly, to indicate an act that has already occurred and secondly, an act that has yet to happen (al-Maghālasah, 2007, p. 331). Examples are as follows:

أكرمت الضيف: "I honored the guests"

أكل الذئب الخروف: "The wolf was devouring a goat”

5) Ism majrūr Nouns preceded by Prepositions

Genitive nouns placed after jar particles or additions (idafah) or tabi' in the previous ism majrur (al-Maghālasah 2007: 431). The nouns being either Sarīh or mushtaq in the form of mufrad, the $i^{c} r a \bar{b} b$ would be of genitive case ending, as shown below:

مررتثِ بِرجلِ :I walked passed a man"

In the sentence above, the word رجل preceded by the jar particle $\rightarrow$.

6) Na't ism majrur (نعت اسم مجرور) Description of Nouns preceded by Prepositions

$N a$ 't is tabi'ah (adjectives) that gives meaning to matbu' (objects being described) or taken under matbu' (al-Qirshī, 2004, p. 163). It can appear in forms of genitive, accusative as well as nominative after a certain noun to further describe it (al-Maghālasah, 2007, p. 459). Thus, na't ism majrur is a mushtaq Noun that comes after ism majrur. Below is an example of a sentence with the genitive case endings (kasra) as an $i^{c} \mathrm{rab}$ :

قال محمد صلى اله عليه وسلم في الحديث الشريف. "Prophet Muhammad SAW said in his noble hadith”

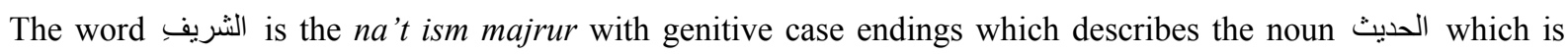
preceded by the jar particle 
Based on this discussion, the constructs in the measurement tools were made with the purpose of gathering information needed for this research, which is further explained in the research methodology.

\section{Methodology}

The format of this study is based on the qualitative approach in terms of data collection and uses quantitive approach to interpret the data. The methodology of this study includes:

\subsection{Participants}

Participants in this study consisted of all students from the Al-Quran Institute of Terengganu undertaking the Malaysian Higher Religion Certificate (STAM) of 2012. The total number of samples was 52 students, of which 32 are boys and 20 are girls.

\subsection{Measurement Tools}

In assessing the comprehension of the Arabic language, researcher has chosen a text written by Syeikh Yusuf al-Qardawi from the website: islamonline.com. The text consists of 448 words, which is the recommended length by Ahmad Tu'aimah (1985, p. 372).

The same text was chosen to assess the understanding of Arabic syntax as well as identifying the frequency of its errors. And from there, researchers cited a total of 18 sentences from the passage with constructs of Arabic syntax that this study is focusing at.

1) Arabic passage comprehension test set.

In this test, students are given the Arabic text passage with 50 blanks to be filled in. Discussions on this test can be found in chapter two under the sub topic Kloz technique, as a tool to evaluate comprehension and level of general reading. Each blank comes with an indirect multiple choice answer. This is because the objectivity of scoring is higher, at the same time ensuring a consistent method of measurement and total scores which are more reliable in assessing the level of comprehension (Aziz, 1989, p. 307). This test was conducted in silent reading and was carried out on students at the same time.

2) Arabic syntax diagnostic test set.

There are 18 questions in this test which represent all 18 sentences cited from the full passage. These sentences are chosen based on constructed Arabic syntactic which is the main focus of this study. Each sentence is provided with a long blank line with three choices of answers. There is only one correct answer. This test is performed individually and students are required to read aloud.

\subsection{Analysis}

The collected data in this study is further analyzed with the Statistical Package of Social Sciences (SPPS) 14.0 software. As a result, the coefficient reliability score of the items in the reading comprehension test is .732 . Meanwhile the Arabic syntax test scored .788 .

1) Comprehension level and stages of general reading.

According to Ta'imah (1985, p. 379), the Kloz technique uses two ways of marking answer sheets, which is when students' answer matches exactly with the original passage or when answers are applicable to the sentences in the passage. However, most researchers are keener on giving marks only when students give the right answer. The rationale in this preference of grading scheme is that it saves more time and prevents biasness amongst examiners.

In analysing Arabic reading comprehension, researchers are leaning more towards the right answer grading in which blanks are filled in with the original words from the passage. Marks are given in percentage by dividing correct answers and the total number of questions/blanks in the passage.

The reading comprehension marks will then be used as criteria to determine the level of general reading as what has been done by Davies and Vincent. There are three stages of general reading, namely, unattended reading, attended reading and the dissatisfactory stage. These three stages of reading comprehension is classified based on the total score in percentage, that is $75 \%$ to $100 \%$ for unattended reading, $26 \%$ to $74 \%$ for attended reading and $0 \%$ to $25 \%$ dissatisfactory. These specific scales are constructed with purposes which are related to students' level of reading comprehension as well general reading stages.

2) Level of Arabic syntax proficiency

The diagnostic test marks obtained will be put into the Table of distribution frequency to facilitate data analysing and interpretation of students' understanding and performances. The scores will then be summed up to get a min 
score in the diagnostic test of Arabic syntax. The level of students' competency is determined based on the assessment scale being used by the Malaysian Religion Higher Certificate, Malaysian Examination Board.

\section{Findings}

Based on analysis, the discussion in this subtopic can be divided into two parts. Specifically, the analysis of reading proficiency and the analysis of syntactic understanding of respondents.

\subsection{Reading Proficiency}

The distribution of scores obtained from the reading proficiency test is shown below, in Figure 1. The result shows that scores of $54 \%$ and $56 \%$ had the highest frequency with a total of seven students. Meanwhile, the five scores which rank the lowest are $32 \%, 68 \%, 70 \%$, and $76 \%$ with only 1 student each. Whereas the maximum score is $76 \%$ and minimum is $32 \%$. (See Figure 1).

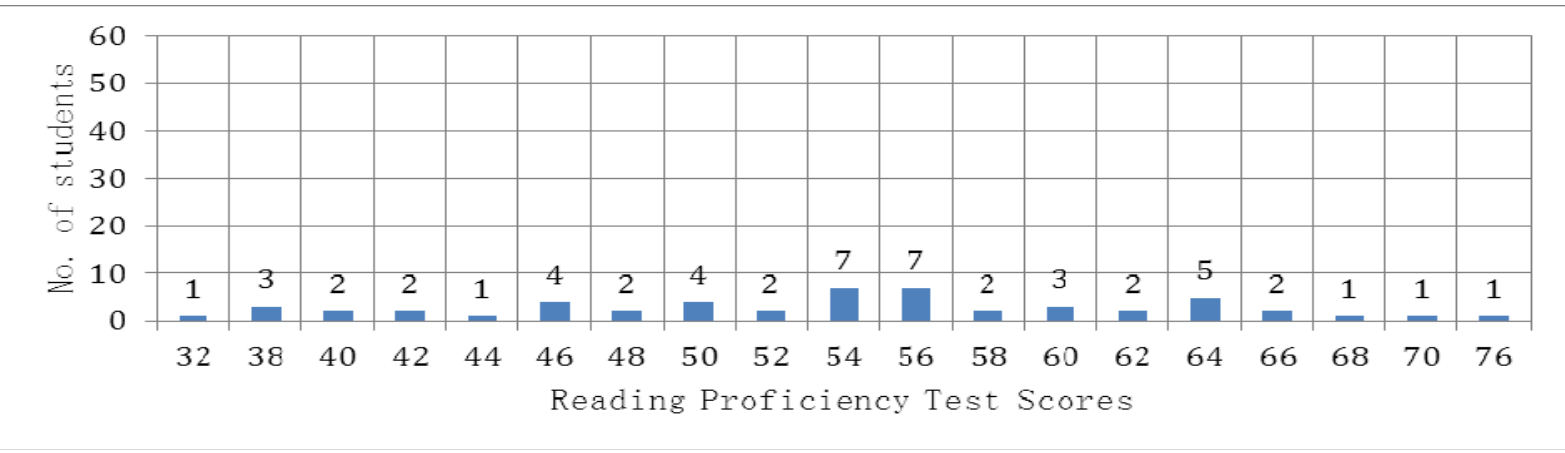

Figure 1. Distribution of reading proficiency scores

Referring to Table 1, only 1 student, representing the $1.92 \%$ obtained the score in between $75 \%$ to $100 \%$, which means that the student sits at the level of unattended reading. There are 51 students representing the other $98.08 \%$ scoring in between $26 \%$ to $74 \%$ placing them in the level of attended reading. Meanwhile no students were reported to fall into the dissatisfactory level. (see Table 1).

Table 1. Level of reading proficiency by frequency

\begin{tabular}{llll}
\hline Range of Scores (x) & Stages of general reading & Frequency (f) & Percentage (\%) \\
\hline $75 \%$ to $100 \%$ & Unattended & 1 & 1.92 \\
$26 \%$ to $74 \%$ & Attended & 51 & 98.08 \\
$0 \%$ to $25 \%$ & Dissatisfactory & 0 & 0 \\
$\mathrm{~N}$ & & 52 & 100 \\
\hline
\end{tabular}

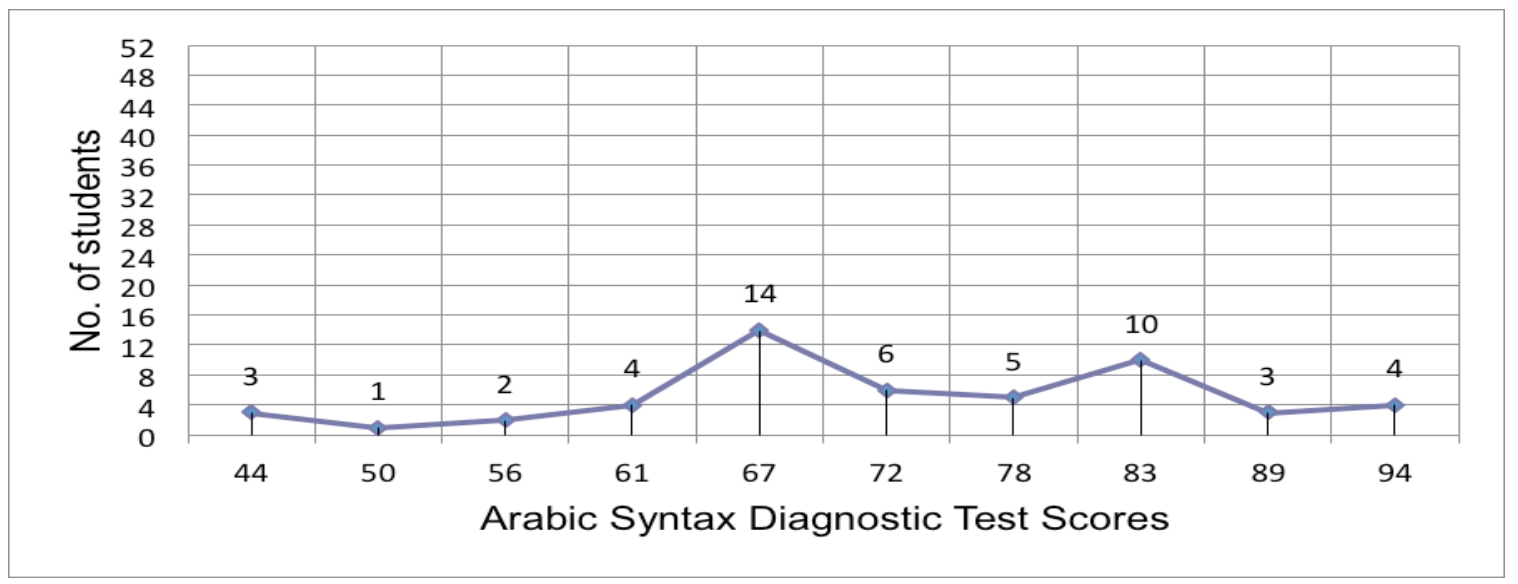

Figure 2. Distribution of arabic syntax diagnostic test scores 


\subsection{Syntactic Competency}

Figure 2 is showing the distribution of scores gathered from the Arabic syntax diagnostic test. Analysis resulted in placing $67 \%$ as the score with the highest frequency with a total of 14 students, followed by $83 \%$ with 10 students. Whereas the score with the lowest frequency is $50 \%$ with only 1 student. The maximum score is $94 \%$ and minimum is $50 \%$. (see Figure 2).

Refering to Table 2, 17 students representing $32.69 \%$ obtained scores in between of $80 \%$ to $100 \%$, which means that they are placed on top in the highest level. Meanwhile 32 students in the other $61.54 \%$ scored $55 \%$ to $79 \%$ putting them in the moderate group. Whilst only 3 students or $5.77 \%$ scored $0 \%$ to $54 \%$ placing them the in all three levels. (see Table 2).

Table 2. Level of Arabic syntax competency by frequency

\begin{tabular}{llll}
\hline Range of Scores (x) & Level of Arabic Syntax Competency & Frequency $(f)$ & Percentage (\%) \\
\hline $80-100$ & Excellent & 17 & 32.69 \\
$55-79$ & Moderate & 32 & 61.54 \\
$00-54$ & Weak & 3 & 5.77 \\
$\mathrm{~N}$ & & 52 & 100 \\
\hline
\end{tabular}

Based on Table 3 above, min score for the construction of Ism Majrūr is 16.36. Followed by Mubtada' which is 15.18. Subsequently, construction of fa' $i l$ with min score of 12.08 and khabar 11.76. Whereas Na't Ism Majrür has the min score of 10.3 and lastly Maf'ül Bih with 7.59. (see Table 3).

Table 3. Min score of diagnostic tests based on construct

\begin{tabular}{|c|c|c|}
\hline Construction & Item & Min Score \\
\hline Mubtada & 7,10 dan 14 & 15.18 \\
\hline Khabar & 8,11 dan 15 & 11.76 \\
\hline Maf́ūl Bih & 2, 5 dan 16 & 7.59 \\
\hline$F \bar{a}^{c} i l$ & 3, 6 dan 12 & 12.08 \\
\hline Ism Majrūr & 1,13 dan 17 & 16.36 \\
\hline$N a^{c} t$ Ism Majrūr & 4, 9 dan 18 & 10.3 \\
\hline Total & & 73.34 \\
\hline
\end{tabular}

*Total score of each construct is 16.67

This shows that students' knowledge on the construction of Maf'ūl Bih is much lesser than the other constructions since the obtained min score is the lowest, which is 7.59 . Whereas students proved to understand the construction of Ism Majrūr very well, with the min score of 16.36 .

\section{Discussion}

In general, the Arabic reading comprehension of students undertaking Malaysian Religion High Certificate (STAM) in the Institute of al-Quran, Terengganu is still at the level of attended reading with an average score of 53.73. It is believed that students are facing some difficulties in reading and comprehension, which means that students need to be given proper guidance and assistance in both aspects such as exposing them to a more effective reading strategy. In a study conducted by Poole (2009), both boys and girls tend to use the same reading strategy but girls seem to be diligent in the pursuit as compared to boys. Mokhtari \& Sheorey (2002) also stated in their study that when students get creative in learning a certain foreign language, their grasp of the new language seems to be faster.

In order for improvements to take place, several reading strategies need to be implemented in the Arabic language classes. The study conducted by Morales \& Holguin (2009) stated that students are supposed to be given guidance using the right reading strategy based on the reading materials, wherein learning modules have to stimulate students' minds to think and read at the same time, encourage students to learn independently and at the same time ensuring teachers are given adequate trainings so that they will be able to help students develop 
their true potentials. Among the reasons which leads to this situation can be referred to students' lack of exposure in the style of language used in writing Arabic as well as limited knowledge of its vocabulary (Suhaila Ahmad et al., 2011, p. 417). Besides that, it can also be caused by incompetent language instructors, subject modules as well as inadequate teaching aids (Huwaydi et al., 2011, p. 705).

At the same time, reading materials need to be suitable and captivating so that students will be more interested to read in Arabic. Wherein this study had chosen a text, which is classified as academic reading that may cause most respondents to lose interest. A study by al-Nafisah \& al-Shorman (2010) concluded that students of a Teacher's College tend to choose their literary reading materials based on interest, teacher's recommendations, and characters in the stories, length and quality of the reading materials as well as how much money they will have to pay for them. This can pretty much be related to the abilities in mastering reading comprehensive skills. The same study also mentioned that some respondents believed that reading skills is not as important as improving other language skills.

As for the understanding of Arabic syntax, students from the same institute are placed at the moderate level as the average score of the diagnostic Arabic syntax test is 72.52. Similar to the viewpoint of scholars in past studies stating that the aspect of Arabic syntax is the main problem especially when it comes to Malay students because more often than not, methods of teaching and students' expectations are never in line with each other (Mat \& Goh, 2010). This may be caused by the method being used by language instructors teaching syntax depending solely on textbooks curriculum without taking into account students' abilities in the difficulty level of the constructions. Language teachers need to be more sensitive in this matter so that students will be able to comprehend the subject more effectively.

According to Naimah Abdullah (2003), Sulaiman Ismail (1996) did a research on errors in constructions of adjective phrases among high school students while Halim Daud (2001) was focusing more on object phrases in Arabic. Both studies supported research done by Raja Mohd Fauzi, Mowafak \& Mohamed Amin (1999, p. 116) which stated that most religious school students in Malaysia do not have a strong command in the Arabic language, either in reading comprehension, writing, speaking or listening. At the same time, most Malaysian students are facing difficulties in mastering Arabic grammar as well (Zaman \& Taib, 2011, p. 205). In fact, mistakes are often made in placements of grammatical case endings while reading (Salamiah et al., 2011, p. 389).

University undergraduates majoring in Islamic Studies are facing the same problems. Even though they are widely exposed with the Arabic language via textbooks and lectures, their grasp of the language is still below par. Idris, Siti Saudah \& Roziah (2002, pp. 9-10) in their research stated that overall, the 52 students of Islamic Studies from the Islamic National University were still not able to master Arabic with excellence. Most students scored $50 \%$ to $62.5 \%$ putting them on the moderate level. Not even one student excelled with scores in between $75 \%$ to $100 \%$. The most worrying part is that this could implicate things in the future as students' command of the language will deteriorate making it more difficult for them to understand the Quran, Hadiths as well as books of past scholars (Shahrin, 1995, p. 6).

\section{Conclusion}

The Arabic language is known to be the medium or wasilah for Muslims in strengthening Islam, faith and worship. Thus, the language holds a significant place in the Muslim community of different race and nations including the Malay Muslims. Teaching and learning of the Arabic language has to be improved from time to time and every party is responsible for it. Rooting from the curriculum makers and sprouting to all learners, each has a role to play in ensuring the level of Arabic language competency gets better towards achieving excellence.

Meanwhile, academicians need to look harder into what are lacking and all sorts of weaknesses students are facing in the process of learning Arabic. Perpetual studies for improvements in the field of Arabic linguistics should be given strong support and encouragement. Language instructors must also seek to find a way in ensuring students' comprehension covers every corner in the Arabic language commands. This is because putting Arabic into practice would require an excellent understanding in all aspects of the language such as syntax, morphology, phonology as well as vocabulary. The main challenge being faced here would be on finding ways to help students master all of them using the language skills approach. Translation approach for Arabic teaching is considered an alternative to enhance student skill in language acquisition. Mat (2011; Mat et al. 2014) suggest that appropriate Arabic to Malay translation process will give more understanding of Arabic structure and syntactic function. 


\section{References}

Abdullah, N. (2003). Analisis Sintaksis Bahasa Arab dan Implikasi Kesilapannya ke atas makna. PhD Thesis. Kuala Lumpur: Universiti Malaya.

Ahmad, S. Ghani, S. A., Sa`dun, Z. M., \& Mustafa, N. (2011). Ahammiyyah Taqniyyah SQ3R fi Ta līm al-Qirā'ah al-Fahmiyyah. Dalam Maheram Ahmad, Mohd Shukari Hamzah, Moktar Hussain, Zhang Hong @ Ammar, Xue Qing Guo @ Bassam, Hakim Zainal \& Suhaila Hj. Zailani (pnyt.). Seminar Antarabangsa Pengajaran Bahasa Arab: Wawasan Dan Cabaran Malaysia-China. Unit Bahasa Arab. Fakulti Pengajian Islam. Bangi: Universiti Kebangsaan Malaysia.

al-Bābitī, ${ }^{c}$ A. F. (1992). al-Mu'jam al-Mufassal fi al-Nahw al-'Arabiyy. Jil 1-2. Beirut: Dār al-Kutub al- ${ }^{\mathrm{c}}$ Ilmiyyah.

al-Maghālasah, M. H. (2007). al-Nahw al-Shāfì al-Shāmil. Amman: Dār al-Masīrah.

al-Rāmīn̄̄, F. (2009). Minhal Al- ${ }^{c} a z a b$ fi Tadris Maharaat al-Qirā'ah wa al-Kitābah Ru'yah Tatwīriyyah: Nazariyyah Tashkhīsiyyah Wa Tatbīqiyyah. 'Ain: Dār al- Kitāb al-Jāmi .

Awaluddin, S. (1995). Pendidikan Bahasa Arab Dan Pembangunan Insan Abad ke 21. Kertas kerja yang dibentangkan di Seminar Kebangsaan Pendidikan Negara Abad ke 21. Dewan Kuliah IV. 7-9 November. Universiti Kebangsaan Malaysia, Selangor: Bangi.

Aziz, A. (1983). Pengajaran dan Penilaian dalam Aspek Lisan dan Membaca di Sekolah Rendah: Fikiran-Fikiran Mengenai Pendidikan Di Malaysia. Dlm. Khoo Phon Sai (Pnyt). Fikiran-Fikiran Mengenai Pendidikan Di Malaysia. Kuala Lumpur: Utusan Publications Dan Distributors Sdn. Bhd.

${ }^{\mathrm{c}}$ Abduh, D. (1990). Nahwu Ta ${ }^{c}$ limu al-Lughah aAl- ${ }^{c}$ Arabiah Wazifiyyan. Jordan: Darul Karmal.

${ }^{\mathrm{c}}$ Aqil, I., \& ${ }^{\mathrm{c}}$ Abdullah, B. A. (1999). Sharh Ibnu ${ }^{c}$ Aqil. Jil. 1-2. Qāherah: Dār al-Kitāb al-Misri.

Fauzi, R. M., Mowafak, \& Amin, M. (1999). The Acquisition of Arabic Reading Coprehension Skills Among Religious Secondary School Students: A Pilot Study. Jurnal Pendidikan. Jilid 24. Mei 1999. Hlm. 115-131. Kuala Lumpur: Universiti Malaya.

Ghani, S. A., Hashim, U. H., Ahmad, S., \& Ahmad, M. (2011). Al-Tajrubah fī Ta ${ }^{c}$ lim MahÉrah Al-Qirā'ah fī Kulliyyah Al-Dirasāt Al-Islāmiyyah. Kertas Kerja. Seminar Antarabangsa Pengajaran Bahasa Arab: Wawasan Dan Cabaran Malaysia-China. Unit Bahasa Arab. Fakulti Pengajian Islam. Bangi: Universiti Kebangsaan Malaysia.

Harris, A. J., \& Sipay, E. R. (1981). How to Increase Reading Ability. Cetakan Ketujuh. New York: Longman Inc.

Hishām, I., \& Yūsuf, J. 'A. B. (1997). Awdah Masālik. Jil.1-2. Beirut: Dār al- Kutub al- ${ }^{c}$ ilmiyyah.

Husin, K. (1988). Pedagogi Bahasa. Selangor: Longman Malaysia Sdn.Bhd.

Huwaydi, M., Ghani, T. A., \& Ahmad, S. (2011). 'Awāmil al-Qusūr litanmiyyah Mahārāt al-Qirā'ah al-Sāmitah li ${ }^{T} a^{c} \lim$ al-Lughah al- ${ }^{c}$ Arabiyyah wa Turuq Tadrīsihā. Dalam Maheram Ahmad, Mohd Shukari Hamzah, Moktar Hussain, Zhang Hong@Ammar, Xue Qing Guo@ Bassam, Hakim Zainal \& Suhaila Hj. Zailani (pnyt.) Seminar Antarabangsa Pengajaran Bahasa Arab: Wawasan Dan Cabaran Malaysia-China. Unit Bahasa Arab. Fakulti Pengajian Islam. Bangi: Universiti Kebangsaan Malaysia.

Jelas, Z. M. (1987). Teori-Teori yang Berhubungan dengan Menguji Kefahaman Membaca. Dlm. Azman Wan Chik (pnyt). Isu-Isu dalam Pengukuran Dan Penilaian Bahasa Malaysia. Kuala Lumpur: Dewan Bahasa Dan Pustaka.

Jinnī, I., \& ${ }^{c}$ Uthmān, A. A. (t.t). Al-Khasāis. Qāherah: Dār al-Kutub.

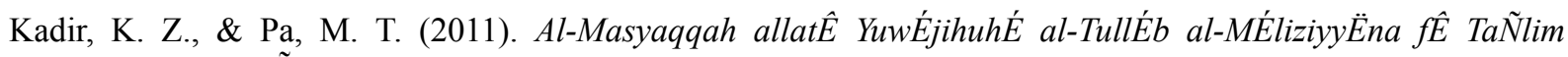
al-Lughah al-ÑArabiyyah. Dalam Maheram Ahmad, Mohd Shukari Hamzah, Moktar Hussain, Zhang Hong @ Ammar, Xue Qing Guo@ Bassam, Hakim Zainal \& Suhaila Hj. Zailani (pnyt.) Seminar Antarabangsa Pengajaran Bahasa Arab: Wawasan Dan Cabaran Malaysia-China. Unit Bahasa Arab. Fakulti Pengajian Islam. Bangi: Universiti Kebangsaan Malaysia.

Lado, R. (1980). Mengajar Bahasa: Suatu Pendekatan Saintifik. Kuala Lumpur: Dewan Bahasa Dan Pustaka.

Mat, A. C. (2012). Conceptual Model of Translation Approach in Foreign Language Teaching and Learning. International Journal of Social Sciences \& Education, 2(3). 
Mat, A. C., \& Soon, G. Y. (2010). Grammar in the classroom: Students' expectations and reality the case of arabic and mandarin. Novitas-ROYAL (Research on Youth and Language), 4(1), 51-63.

Mat, A. C., Yaakub, A. M. N., \& Tajuddin, N. A. (2014). Translating Circumstantial Clause of Arabic into Malay. Asian Social Science, 10(13), 72. http://dx.doi.org/10.5539/ass.v10n13p72

Rahman, M. Z. A., \& Mezah, C. R. (2010). Ciri-ciri Bahasa Arab: Fonetik, Morfologi dan Sintaksis. Serdang: Universiti Putra Malaysia.

Rejab, H. M. (2011). Tajrubah Mālīziya fi Tanfiz Barnāmij Shahādah Dīniyyah Malīziyyah. Kertas Kerja. Prosiding Seminar Antarabangsa Pengajaran Bahasa Arab: Wawasan Dan Cabaran Malaysia-China. Unit Bahasa Arab. Fakulti Pengajian Islam. Bangi: Universiti Kebangsaan Malaysia.

Rushdī., T. A. (1985). Dalil ${ }^{c}$ Amal fi I $I^{c} d \bar{d}$ al-Mawād al-Ta lìmyyah li al-Barāmij Ta ${ }^{c}$ lìm al- ${ }^{c}$ Arabiyyah. Maahad Lughah ${ }^{c}$ Arabiyyah. Makkah: Jāmic ah Ummu Qurā.

Rusoff, A. M. (2008). Halatuju Pengajaran Bahasa Arab Dalam Program j-QAF Di Malaysia. Kertas kerja. Seminar Pengajaran Bahasa Dan Kesusasteraan Arab Di Institusi Pengajian Tinggi Malaysia. Bangi: Universiti Kebangsaan Malaysia.

Talib, A. A. A. (1989). Bacaan Nyaring: Nilai dan Peranannya dalam Bidang Pendidikan Bahasa Malaysia Kini. Dlm Abdul Aziz (Pnyt). Pengajaran Dan Pengujian Bahasa: Perspektif Untuk Guru. Kuala Lumpur: Nurin Interprise Sdn. Bhd.

Talib, A. A. A. (1993). Menguji Kemahiran Bahasa: Prinsip, Teknik dan Contoh. Selangor: Percetakan Dewan Bahasa Dan Pustaka.

Yunus, K. R. M. (1987). Ujian Kefahaman Membaca. Dlm. Azman Wan Chik (pnyt). Isu-Isu dalam Pengukuran dan Penilaian Bahasa Malaysia. Kuala Lumpur: Dewan Bahasa Dan Pusaka.

Yusoff, M. (1999). Strategi Pengajaran Bacaan dan Kefahaman. Selangor: Percetakan Dewan Bahasa Dan Pustaka.

\section{Appendix A}

Table A1. Scale of general reading criteria

\begin{tabular}{|c|c|c|}
\hline Marks & Stages of General Reading & Description \\
\hline $0 \%$ to $25 \%$ & Dissatisfactory & $\begin{array}{l}\text { Student faced a great deal of difficulties in reading and } \\
\text { comprehension that led to frustration. }\end{array}$ \\
\hline $\begin{array}{l}26 \% \\
74 \%\end{array}$ & Attended & $\begin{array}{l}\text { Student faced some difficulties and guidance is needed to } \\
\text { help in reading and comprehension. }\end{array}$ \\
\hline $\begin{array}{l}75 \% \\
100 \%\end{array}$ & Unattended & $\begin{array}{l}\text { Student is competent in reading and understanding what is } \\
\text { being read without help or guidance. }\end{array}$ \\
\hline
\end{tabular}

Table A2. Scale of grammar (nahw) test marks

\begin{tabular}{lll}
\hline Range of Scores & Ranking & Level \\
\hline Mumtaz & Excellent \\
Jayyid Jiddan & Moderate \\
Jayyid & Maqbul \\
Rasib & Weak \\
\hline
\end{tabular}

\section{Copyrights}

Copyright for this article is retained by the author(s), with first publication rights granted to the journal.

This is an open-access article distributed under the terms and conditions of the Creative Commons Attribution license (http://creativecommons.org/licenses/by/3.0/). 